\title{
Accounting Conservatism Trends and Financial Distress: Considering the Endogeneity of the C-Score
}

\author{
Hui-Sung $\mathrm{Kao}^{1}$ \& Pei-Jhen Sie ${ }^{1}$ \\ ${ }^{1}$ Department of Accounting, Feng Chia University, Taichung, Taiwan \\ Correspondence: Hui-Sung Kao, Associate Professor, Department of Accounting, Feng Chia University, No. 100, \\ Wenhwa Rd., Seatwen, Taichung 40724, Taiwan. Tel: 886-4-2451-7250 Ext. 4221.
}

Received: December 20, 2015

Accepted: January 4, 2016

Online Published: July 7, 2016

doi:10.5430/ijfr.v7n4p149

URL: http://dx.doi.org/10.5430/ijfr.v7n4p149

\begin{abstract}
To consider a firm's characteristics endogeneity and thereby determine its trend toward accounting conservatism, which in turn affects its financial distress, this study adopts the two-stage least squares approach. The first stage involves investigating the effect of the corporate characteristics on accounting conservatism. The empirical results indicate that financial distress and accounting conservatism exhibit a positive correlation. With respect to the non-financially distressed company, the accounting conservatism of the financially-distressed company is higher. The second phase in the logistic regression is to explore the relationship between the accounting conservatism trends and financial distress. The empirical results indicate that the trends and volatility of the accounting conservatism are significant and positively related to the financial distress, which may be due to the recognition of the company's annual loss on one occasion or the accountants' role in the function of exercising external oversight, thus increasing the company's accounting conservatism. According to the empirical results of this study we have found that the accounting conservatism trends of different company characteristics helps to determine the signs of financial distress. It is recommended that within the management of the company's operations the users of financial statements be aware of the trend and volatility of the accounting conservatism. This is of particular importance due to the probable development of the relevant decision-making processes of the company's stakeholders.
\end{abstract}

Keywords: accounting conservatism, financial distress, corporate characteristics, corporate governance

\section{Introduction}

A warning of financial distress is a serious concern not only in academic circles but also practical circles. While past studies on early warning signs of financial distress focused on financial indicators in financial reports, recent studies have utilized different econometric models in which not only financial variables, but also non-financial variables for different fields, such as corporate governance, intellectual capital and stakeholders' transactions have been added, with a view to enhancing the fitness and predictive power of the model. However, most of them have only changed the econometric models or corrected the variables. Few of them have explored pure firm characteristics or the characteristics of the accounting approaches adopted. The causes of a firm's financial distress are complicated, such as a high debt ratio, inadequate cash flow and stockholders' transactions, and in addition to the financial indicators, other factors like the external environment, poor management or improper management strategies can also cause firms to experience financial distress and collapse. Besides the data disclosed in the financial reports, if firm managers intentionally falsify accounting records, the distress will be more serious, as can be found in the cases of Enron (US), WorldCom (US), Procomp (Taiwan), and ABIT (Taiwan). However, these signs are deliberately concealed and ambiguous and unobvious. Thus, the decision to only use traditional financial indicators is that they cannot be found. In these cases, some studies have added non-financial variables.

Most of the more recent studies on financial distress have started to discuss non-financial indicators such as corporate governance. In addition, accounting and financial policies, approaches and attitudes may also affect the results expressed by financial reports. The financial reports only reflect the current and past financial information, and the firm characteristics can be reflected in their trends in financial reports and then endogenously affect the probability of the financial distress. For example, Enron Corporation adopts a relatively radical accounting method, and TSMC (Taiwan Semiconductor Manufacturing Co., Ltd.) uses a more conservative accounting treatment approach. The different characteristics of the firms can be observed from the financial approach adopted, namely, 
accounting conservatism. For example, attitudes towards accounting and financing planning can represent characteristics of conservative or radical firms, which can be reflected in the accounting conservatism trends in financial reports. The probability of financial distress can be indirectly inferred from the trend, which is useful in predicting a financial crisis. For example, if a firm has a relatively conservative management and financial operating mode, it may adopt a more conservative recognition in its accounting treatment and data in its financial reports. Such a firm exhibits conservative characteristics. In other words, each firm has its firm-specific characteristics, which can be reflected in its financial reports, which means that the firm's organizational culture characteristics lie in the data in their financial reports.

This study considers that firm characteristics can be reflected in the financial reports. When the characteristics of a firm are conservative, it will prudentially assess the future management environment, which implies relatively conservative characteristics of the firm, and it will also carefully consider the operation or investment, as this can reduce the probability of risk caused by the firm's financial difficulties. Alternatively, the firm may already exhibit signs of financial distress, so that the accounting firms that perform external audits will be more conservative because they are afraid of litigation risk, or perhaps the firm will make a one-off recognition of all losses in deficit years, and thus the trend toward conservatism of the distressed firm will be higher or will increase.

Accounting conservatism will recognize all probable losses as they are discovered and revenue will be deferred until it is verified. From the perspective of empirical research, conservatism is characterized by asymmetric timeliness in terms of its recognition of profits and losses (Basu, 1997). That is, the response to bad news is faster than that to good news, so that assets tend to be underestimated (Roychowdhury and Watts, 2007). These two views are based on the high degree of checking and verification required for recognized assets. If the criterion for the recognition of profits is stricter than that for losses in the profit and loss statements, the accounting figures can reflect a higher level of accounting conservatism. Watts (2003a) considers that such deferred profits, which have characteristics resulting in lower net assets, can reduce issues of moral crisis. The accounting conservatism, such as the real-time recognition of losses, can contribute to a review of the firm's potential risks.

This study is intended to investigate firms with specific characteristics. Their attitudes towards accounting treatment approaches can be reflected in their degree of accounting conservatism. Their accounting conservatism trend may be correlated with the probability of a financial crisis. This indicates that financial distress and accounting conservatism may affect each other endogenously. For the factors describing firm characteristics, Coles, Daniel and Naveen (2008) use the debt ratio, $R \& D$ orientation and complexity to distinguish firm characteristics. Based on the literature, this study considers the use of other factors to describe firm characteristics, such as growth, the return on assets, and the age of listed firms, and utilizes the C-Score which can compare characteristics across firms on a year-on-year basis to extract firm intrinsic characteristics which can be reflected in the accounting conservatism trend in financial reports. The focus of this study is on exploring the influence of the accounting conservatism trend of the firms with different characteristics on financial distress. This study introduces the accounting conservatism trend before the output of financial reports and considers the endogenous factor of self-selection of accounting policies in firms, in order to understand the causes forming the trend of accounting indicators before the event based on the traditional post-event accounting indicators. In other words, this study intends to discuss the correlation between the accounting conservatism trend and the financial distress, and to take account of the endogenous impact of accounting policies by the firms and their attitudes, with a view to serving as a reference for the competent authorities and investors to judge the possibilities of financial distress, and fill the gap in the prior literature.

The empirical results show that the accounting conservatism trend of different firms can help to identify the signs of financial distress, which is the academic contribution of this study. The characteristics of the firms can endogenously determine the accounting conservatism trend, which in turn can affect the occurrence of financial distress. As for the contribution to practice and the management implications, based on the empirical results, this study recommends that users of financial reports pay attention to changes in the trend of accounting conservatism, which can serve as a reference for stakeholders to make decisions about relevant policies. Thus, the accounting conservatism trend and change can be used to detect early signs before the occurrence of financial distress in the future, and then predict the possibility of financial distress, thereby serving as a reference for competent authorities and investors to determine the possibility of financial distress.

The remainder of this paper is organized as follows. Section 2 provides a review of the literature. Section 3 explains the research design including the data sources, sample selection, variable definitions and empirical model. The empirical results and analysis are presented in Section 4. Finally, the conclusions as well as some suggestions are presented in Section 5. 


\section{Literature Review and Hypothesis}

\subsection{Accounting Conservatism}

The conservatism principle is a very important accounting principle. Sterling (1970) rates conservatism as the most influential principle of valuation in accounting. In empirical studies on accounting conservatism, the reverse regression model constructed by Basu (1997) has both a crucial contribution and influence. Many scholars use this model for the analysis and investigation of issues (Ball \& Shivakumar, 2005). Following that, much of the literature uses the Basu model to verify the conservatism of capital markets in different countries, and extends the Basu model to explore factors affecting the level of conservatism (Ball, Sadka, and Sadka, 2009; Ball and Shivakumar, 2005; Beaver, Landsman, and and Owens, 2012; Francis et al., 2004; Francis and Wang, 2008).

Watts (2003 a, $2003 \mathrm{~b}$ ) considers that the users of financial reports may have different needs for accounting conservatism due to different firm operating characteristics. For example, the users may have a high need for the accounting conservatism of financial reports when the firms have more serious information asymmetry or agency problems (LaFond \& Roychowdhury, 2008; LaFond \& Watts, 2008) or high litigation risk (Holthausen \& Watts, 2001; LaFond \& Roychowdhury, 2008). Khan and Watts (2009) indicate that if the age of a firm after an IPO is shorter, the existing asset value of the firm may have more opportunities for growth, as compared to a firm which is older after an IPO. As the cash flow for future growth cannot be verified, an increase in information asymmetry between managers and investors can increase the need for accounting conservatism. A paper by Wang et al. (2012) uses the method provided by Khan and Watts (2009) to verify the effectiveness and applicability of the C_Score in the capital market in Taiwan. Their study demonstrates that the results for accounting conservatism as measured by the C_Score are consistent with those from using the Basu model, thereby providing evidence for the applicability of the C_Score in different countries.

Ahmed et al. (2002) point out that the costs of conservative accounting are higher when the firm's profitability is lower. Thus, the firms with higher profitability may also adopt conservative accounting. If the industry category is different, the profit models are different due to industry characteristics. Chi et al. (2009) suggest that there are two different perspectives regarding the relationship between corporate governance and accounting conservatism. One is the complementary perspective and the other is the substitutionary perspective, and their findings show that a substitutionary relationship exists between the corporate governance mechanism and accounting conservatism. If the corporate governance is better, the need for accounting conservatism is lower. However, the findings obtained by Lara, Osma and Penalva (2009) show when the corporate governance mechanism is better, accounting conservatism increases, and there exists a causal relationship. Ramalingegowda and $\mathrm{Yu}$ (2012) anticipate and find that if the institutional investors with the motivation to exercise supervision hold more shares, the firms will be more inclined to adopt the conservative accounting principle. Besides, the more growth opportunities there are for firms, or the more serious the information asymmetry, the more difficulty the institutional investors will have in supervising the maximization of benefits by management, and the greater will be the need to depend on conservative accounting for the governance and supervision of firms.

\subsection{Financial Distress}

Domestic and foreign scholars and experts have different views regarding the definition of "financial distress", and there has not been any consistent definition so far. Some scholars define it as a delay in the payment of debts or insolvency, the failure to pay when an extension of credit expires, a suspension, an adjudication of bankruptcy, and going private. The other scholars define it as a negative net value, insolvency, liquidation or bankruptcy. Ohlson (1980) and Shumway (2001) use the firm's total scale to measure whether operational difficulties are related to firm size, and find that the greater the firm's scale, the more abundant are its economic resources. Therefore, the risk of financial distress that they face is smaller. The financial distress early warning models established by the Z-Score by Altman (1968) and the logistic regression by Ohlson (1980) reveal that, among the different financial variables, profitability and the debt ratio (financial structure) are the causes of financial distress.

Chava and Jarrow (2004) argue that different industries may face different degrees of competition and accounting ratio characteristics, so their default situations are not exactly the same. Berkovitch and Israel (1998) indicate that the default of relatively mature industries is less than that of growing industries as the underestimation of investment by mature industries is not serious. Shumway (2001) indicates that a firm can be listed only if it meets the requirements of listed companies specified by an exchange. The homogeneity among firms is high when firms have only just been listed. That is, the firms have the ability to raise funds in the capital market. As the ages of the firms increase, their operational risk and uncertainty may decrease. If they face some financial situation, they can overcome it. Thus, the probability of the occurrence of financial distress will be reduced. Daily and Dalton (1994) explore the relationship 
between an enterprise's bankruptcy and the corporate governance structure. They use financial and non-financial indicators for five years before the bankruptcy as the control variables and conduct Logit analysis to predict the financial distress. The findings show that the added corporate governance variables such as the equity structure and board characteristics can improve the accuracy of the model. Rezaee (2005) suggests that the corporate governance information can be used to detect and prevent the reporting of false financial information.

\subsection{Corporate Characteristics, Accounting Conservatism and Financial Distress}

Watts (2003 a, $2003 \mathrm{~b}$ ) proposes that the users of financial reports have economic needs for accounting conservatism in terms of contracts, litigation, governance and taxes and levies. If firms' operating characteristics are different, the need for conservative accounting is different. For example, the need for conservative financial reports is higher when a firm has agency problems or more serious information asymmetry (LaFond \& Roychowdhury, 2008; LaFond and Watts, 2008), or higher litigation risk. The financial distress early-warning models established by the Z-Score by Altman (1968) and logistic regression by Ohlson (1980) reveal that, among the financial variables, profitability and the debt ratio (financial structure) are the causes of financial distress. Chava and Jarrow (2004) argue that the default of different industries is affected by different degrees of competition and accounting ratio characteristics. Shumway (2001) indicates that the age of a listed firm may affect the probability of it experiencing financial distress. By referring to the above and previously mentioned literature, the factors affecting firm characteristics have been summarized, and include growth opportunities, profitability, industry category, the age of listed firms and so on. It is anticipated that firm characteristics are related to accounting conservatism and financial distress.

From the literature, we can find a number of studies on agency problems. For example, Jensen and Meckling (1976) propose the traditional agency problem, between the principal and agent, and La Porta, Lopez-de-Silanes, Shleifer, and Vishny (1999) find evidence of a core agency problem. All these problems may exist in business organizations at the same time, and the firm will hope to solve them through the corporate governance mechanism. Prior empirical studies have given rise to inconsistent results regarding the relationship between the corporate governance mechanisms and accounting conservatism. Some studies find that the corporate governance is positively correlated with accounting conservatism (Ahmed and Duellman, 2007; Beekes, Pope, and Young, 2004), others show that they are negatively correlated (Bushman, Chen, Engel, and Smith, 2004; LaFond and Roychowdhury, 2008), while yet others find that they are not correlated. In addition, Chi et al. (2009) indicate that there are two different perspectives regarding the relationship between corporate governance and accounting conservatism, with one being complementary and the other substitutionary. On the basis of complementarity, a sound corporate governance mechanism can provide stronger supervision for managers, and so it is anticipated that managers will be willing to adopt conservative accounting under pressure. That is, the better the corporate governance, the more conservative will be the financial reports. On the basis of substitutability, the worse the corporate governance mechanism, the more serious the agency problems become, and so the need for conservative accounting increases. That is, the worse the corporate governance mechanism, the greater the need for accounting conservatism. From the above relevant literature, the corporate governance-related factors are related to the probability of financial distress. This study lists the corporate governance as the research variable for the firm characteristics in discussing the correlation between the corporate governance characteristics as the variable and accounting conservatism and financial distress. Thus, H1 is developed as follows:

\section{H1: Some firm characteristics are simultaneously correlated with accounting conservatism and financial distress.}

\subsection{Accounting Conservatism and Financial Distress}

An early warning of a firm in financial distress has always been a major concern in academic and practical circles. In the past, scholars mainly used financial information to predict the financial distress of firms. Recent studies have added corporate governance and other non-financial indicators besides the traditional financial information. For example, Lee and Yeh (2004) argue that the worse the corporate governance mechanism is, the higher will be the probability of financial distress. Besides, Lara, Osma and Penalva (2009) predict that the degree of accounting conservatism is higher when the corporate governance is better. From the above study, it can be found the corporate governance can affect accounting conservatism and financial distress simultaneously, and corporate governance can be viewed as a generalized firm characteristic.

Chen (2006) explores the relationship between accounting conservatism and the probability of financial distress and finds that firms with higher accounting conservatism have a lower probability of financial distress, which reveals that the firms with higher accounting conservatism have better financial health. That is, the accounting conservatism can increase the earnings quality of the firms, and thus the portability of financial distress is lower in the firms. Huang (2009) takes distressed firms from the Chinese mainland and discusses the relationship between the corporate 
governance and accounting conservatism in the distressed firms and normal firms and the change in the relationship between the corporate governance and accounting conservatism before and after the financial distress. The empirical results show that the firms experiencing a financial crisis have a higher degree of accounting conservatism than the firms that do not experience a financial crisis. As compared to the normal firms, when the corporate governance mechanism in the distressed firms deteriorates, there is an incentive to defer the recognition of losses, and so they provide financial reports without accounting conservatism.

Based on a review of prior studies, the relationship between accounting conservatism and financial distress exhibits an inconsistent impact as each firm has specific characteristics. As for the firms with certain characteristics, their adopted accounting policies and accounting treatment methods and attitudes can be reflected in their degree of accounting conservatism, and furthermore these characteristics may affect the probability of financial distress. Thus, the accounting conservatism should be used to predict the financial distress. In other words, some firm characteristics that can affect accounting conservatism may also affect the probability of financial distress. These characteristics may even have affected accounting conservatism several years before the financial distress. That is to say, the problem of endogeneity exists among the accounting conservatism, firm characteristics and financial distress. Firms with different characteristics may adopt different accounting policies and accounting treatment approaches which can be reflected in accounting conservatism, and thus there is a self-selection problem. The firm characteristics may also endogenously affect the accounting conservatism trend and increase the financial distress. Prior studies discuss the correlation between the accounting conservatism and different degrees of accounting conservatism and financial distress. Recent studies have not explored the impact of the trend toward accounting conservatism on financial distress. Another contribution of this study is that it uses the accounting conservatism trend as a measurement basis. Thus, $\mathrm{H} 2$ is developed as follows:

\section{H2: The accounting conservatism trend may endogenously affect the probability of financial distress.}

\section{Research Design}

This study intends to explore the firm characteristics reflected in the accounting conservatism trend. As the firm characteristics can endogenously determine the accounting conservatism trend and further affect the occurrence of financial distress, this study uses two-stage least squares (2SLS) to discuss the correlation between the accounting conservatism trend and financial distress.

\subsection{Data Sources and Sample Selection}

This study assesses listed firms whose stocks are traded on the stock exchange and in the over-the-counter (OTC) market in Taiwan, and excludes financial and insurance companies whose financial data cannot be considered as variables, for they make up a special industry and their accounting treatment approaches are different from those of ordinary industries. In addition, the firms which do not have relevant data based on financial reports or lack relevant disclosed data are also excluded. Moreover, this study uses the paired sample approach (1: 3) instead of random sampling to reduce error in selection as proposed by Zmijewski (1984) due to the excessive sampling of failed firms and in order to improve each model's applicability. The pairing criterion involves pairing the normal firms with (1) firms for the same year interval, two years before the financial distress, (2) firms in the same industry category and (3) firms with similar total assets; After excluding the financial and insurance companies whose industry characteristics and accounting approaches are different from those of ordinary industries and for firms without relevant financial reporting data and disclosed data, this study collects data for 84 distressed firms and 252 paired normal firms. The final sample consists of 336 observations. The sample selection is as shown in Table 1 as follows.

Table 1. Sample selection

\begin{tabular}{lr}
\hline & Observations \\
\hline Panel A: C-Score Sample & \\
\hline Listed firms and OTC firms from 1999 to 2014 in Taiwan & 22,218 \\
Less: Financial industry & $(679)$ \\
Less: Omitted variables & $\underline{(5,901)}$ \\
Final sample with C-Score & 15,638 \\
\hline Panel B: Financial Distress Sample & 98 \\
\hline Financially distressed firms from 1999 to 2014 in Taiwan & $(14)$ \\
Less: Omitted variables & 84 \\
Final sample of financially distressed firms & \\
\hline
\end{tabular}




\subsection{Empirical Model}

\subsubsection{Corporate Characteristics and Accounting Conservatism}

This study uses 2SLS to demonstrate the relationship between accounting conservatism and financial distress. In the first stage, $\mathrm{H} 1$ examines the effect of corporate characteristics on the accounting conservatism (Model 1). The empirical model is as follows:

$$
\text { C_Score }=\alpha_{0}+\alpha_{1} \text { Distress }+\alpha_{2} G R O W T H+\alpha_{3} R O A+\alpha_{4} I T+\alpha_{5} I P O+\alpha_{6} C G_{-} B O D+\alpha_{7} C G_{-} O W N+\varepsilon
$$

The definitions of the terms are as follows. $C_{-}$Score: Independent variable for accounting conservatism. The firm-year specific C-Score developed by Khan and Watts (2009) is used to measure the extent of the accounting conservatism. Distress: Financial distress, a dummy variable, which equals 1 when the firm exhibits financial distress, and 0 otherwise. GROWTH: The firm's ability to grow, calculated by net sales deflated by net sales in the prior period. $\boldsymbol{R O A}$ : The firm's profitability, calculated using the ROA at the end of the period. ROA is equal to the net income of a going concern divided by total assets $* 100 \%$. IT: The electronics industry, in the form of a dummy variable, which equals 1 when the firm is in the electronics industry, and 0 otherwise. IPO: Age of the firm after an IPO. $\boldsymbol{C G} \_$BOD: Corporate governance score based on board composition. $\boldsymbol{C G} \boldsymbol{O} \boldsymbol{W} \boldsymbol{N}$ : Corporate governance score based on ownership structure.

\subsubsection{Accounting Conservatism Trends and Financial Distress}

The second stage, H2, examines the effect of the accounting conservatism trend on the financial distress (Model 2). The empirical model is as follows:

$$
\text { Distress }=\beta_{0}+\beta_{1} \text { C_S } \hat{c} \text { ore }+\beta_{2} X_{1}+\beta_{3} X_{2}+\beta_{4} X_{3}+\beta_{5} X_{4}+\beta_{6} X_{5}+\varepsilon
$$

The variables are as follows. Distress: An independent variable for financial distress, a dummy variable, which equals 1 when the firm exhibits financial distress, and 0 otherwise. $\boldsymbol{C}$ SS $\hat{\boldsymbol{c}} \boldsymbol{o r} \boldsymbol{e}$ : The trend of accounting conservatism. The first-stage regression is used to estimate the change in the fitted values of the C_Score in the three years of assessment. The method used to measure the change involves calculating the fitted value for the accounting conservatism trend and its variation (standard deviation). The way it is measured is as follows. Accounting conservatism trend $\left(\boldsymbol{C S C O R E} \boldsymbol{C}_{-} \boldsymbol{T R E N D}\right)=$ [The fitted values of the C_Score in the distress year (PC_Score) - The fitted values of the C_Score two years before the distress (PC_Score2)] / The fitted values of the C_Score two years before the distress (PC_Score2). Accounting conservatism variation (CSCORE_STD): This is calculated using the standard deviation of the fitted values of the C_Score from the distress year to two years before the year of distress. $\boldsymbol{X}_{\mathbf{1}} \sim \boldsymbol{X}_{\mathbf{5}}$ : The other control variables in the financial distress model. The five financial ratios of the Z-Score model by Altman (1968) for bankruptcy prediction are used. The control variables include the following. $\boldsymbol{X}_{\mathbf{1}}$ : Working capital divided by total assets. $\boldsymbol{X}_{2}$ : Retained earnings divided by total assets. $\boldsymbol{X}_{3}$ : Net income before tax and interest divided by total assets. $\boldsymbol{X}_{\mathbf{4}}$ : The market value of equity divided by total liabilities. $\boldsymbol{X}_{\mathbf{5}}$ : The sales revenue divided by total assets.

\section{Empirical Results and Analysis}

\subsection{Descriptive Statistics and Analysis}

Table 2 lists the industrial distribution of all the sampled firms, there being 84 distressed firms and 252 normal firms, or a total of 336 firms. The sample data are selected from the firms that had financial distress from 2001 to 2014 among the ordinary industries in the Taiwan Economic Journal database (TEJ). After excluding the financial and insurance companies, the firms which were in the same industry category and were of similar size in terms of assets were paired for the analysis. From Table 2, it can be found that the samples which had financial distress are mainly from the electronics industry and the construction industry, which respectively accounted for $38.1 \%$ and $20.24 \%$ of the total number of firms in the overall sample.

Table 3 lists the descriptive statistics of all of the variables of the sample firms, with a total of 336 observations. From Table 3 Panel A, it can be seen that the mean value of the financial distress is 0.25 for the proportion of the paired samples that is 1:3. Next, the standard deviation of the return on assets (ROA) and the growth is greater than the mean value, and the difference between the maximum value and minimum value is very large. This shows that a greater difference exists between the samples, possibly resulting from the extreme values for sampled firms experiencing financial distress. The mean value for the accounting conservatism (C_Score, C_Score1, C_Score2) is greater than that for the median. According to the variation and changes in the mean value for accounting conservatism (C_Score, C_Score1, C_Score2) and its fitted value (PC_Score, PC_Score1, PC_Score2), it can initially be seen that accounting conservatism exhibits an increasing trend from two years before the financial distress to the year of the financial distress. 
Table 2. Industry distribution of full sample

\begin{tabular}{lcccr}
\hline \multicolumn{1}{c}{ Industry } & $\begin{array}{c}\text { Financially } \\
\text { distressed firms }\end{array}$ & Percentage & Normal firms & Percentage \\
\hline Cement industry & 2 & $2.38 \%$ & 6 & $2.38 \%$ \\
Plastics industry & 4 & $4.76 \%$ & 12 & $4.76 \%$ \\
Spinning and weaving $\quad$ industry & 10 & $11.90 \%$ & 30 & $11.90 \%$ \\
Electrical machinery & 3 & $3.57 \%$ & 9 & $3.57 \%$ \\
Electronic equipment & 1 & $1.19 \%$ & 3 & $1.19 \%$ \\
Chemical products and & 1 & $1.19 \%$ & 3 & $1.19 \%$ \\
$\quad$ Health & 8 & $9.52 \%$ & 24 & $9.52 \%$ \\
Steel industry & 32 & $38.10 \%$ & 96 & $38.10 \%$ \\
Electronics industry & 17 & $20.24 \%$ & 51 & $20.24 \%$ \\
Building materials and & 2 & $2.38 \%$ & 6 & $2.38 \%$ \\
$\quad$ construction & 4 & $4.76 \%$ & 12 & $4.76 \%$ \\
Trading and Retail & $\mathbf{1 0 0 . 0 0 \%}$ & $\mathbf{2 5 2}$ & $\mathbf{1 0 0 . 0 0 \%}$ \\
Other industries & & & &
\end{tabular}

Table 3. Descriptive statistics

\begin{tabular}{|c|c|c|c|c|c|}
\hline \multicolumn{6}{|c|}{ Panel A: First-stage regression (C-Score model) } \\
\hline Variables $^{\mathbf{a}}$ & Mean & Std. Dev. & Median & Min & Max \\
\hline Distress & 0.250 & 0.434 & 0.000 & 0.000 & 1.000 \\
\hline GROWTH & 5.896 & 70.916 & -1.925 & -88.320 & 735.440 \\
\hline ROA & -4.357 & 26.344 & 1.601 & -249.945 & 58.717 \\
\hline IT & 0.384 & 0.487 & 0.000 & 0.000 & 1.000 \\
\hline IPO & 9.643 & 6.831 & 8.000 & 3.000 & 42.000 \\
\hline CG_BOD & 1.726 & 0.572 & 1.800 & 0.150 & 2.950 \\
\hline CG_OWN & 2.507 & 0.602 & 2.475 & 0.940 & 4.030 \\
\hline C_Score & 0.327 & 0.660 & 0.266 & -4.363 & 5.616 \\
\hline C_Score 1 & 0.308 & 0.453 & 0.232 & -0.892 & 3.687 \\
\hline $\mathrm{C}^{-}$Score 2 & 0.234 & 0.213 & 0.202 & -0.360 & 1.825 \\
\hline$N$ & 336 & & & & \\
\hline \multicolumn{6}{|c|}{ Panel B: Second-stage regression (Financial Distress model) } \\
\hline Variables $^{\mathbf{a}}$ & Mean & Std. Dev. & Median & Min & Max \\
\hline Distress & 0.250 & 0.434 & 0.000 & 0.000 & 1.000 \\
\hline $\mathrm{X} 1$ & 0.220 & 0.277 & 0.219 & -0.600 & 0.903 \\
\hline $\mathrm{X} 2$ & -0.147 & 1.053 & 0.097 & -12.546 & 0.710 \\
\hline $\mathrm{X} 3$ & -0.023 & 0.257 & 0.032 & -2.441 & 0.624 \\
\hline $\mathrm{X} 4$ & 2.795 & 4.212 & 1.328 & 0.023 & 34.325 \\
\hline $\mathrm{X} 5$ & 0.904 & 0.642 & 0.763 & 0.004 & 4.898 \\
\hline PC_Score & 0.327 & 0.175 & 0.342 & -0.166 & 0.946 \\
\hline PC_Score1 & 0.308 & 0.181 & 0.326 & -0.220 & 0.743 \\
\hline PC_Score2 & 0.234 & 0.080 & 0.237 & -0.002 & 0.575 \\
\hline
\end{tabular}

a. The definitions of variables: Distress = financial distress; GROWTH = growth power; ROA = profitability; IT = electronics industry; IPO = Age of firms after IPO; CG_BOD = corporate governance score of board composition; CG_OWN = corporate governance score of ownership structure; C_Score = accounting conservatism in the year of financial distress; C_Score1 = accounting conservatism in year before financial distress; C_Score2 = accounting conservatism in two years before financial distress; $\mathrm{X} 1$ = working capital divided by total assets; $\mathrm{X} 2$ $=$ retained earnings divided by total assets; X3 = net income before tax and interest divided by total assets; X $4=$ market value of equity divided by total liabilities; X5 = sales revenue divided by total assets; PC_Score $=$ fitted value of accounting conservatism in the year of financial distress; PC_Score1 = fitted value of accounting conservatism in one year before financial distress; PC_Score $2=$ fitted value of accounting conservatism in two years before financial distress. 
Table 4 illustrates the results of the t-test for differences in the mean values of each variable for the distressed firms and normal firms. From Table 4, it can be observed that the debt-equity ratio (LEV) of the distressed firms is significantly higher than that of the normal firms, reaching a significance level of $1 \%(t=5.106)$. The ROA of the distressed firms is significantly lower than that of the normal firms, reaching a significance level of $1 \%(t=7.569)$. This shows that the LEV of the distressed firms is significantly higher than that of normal firms, and the ROA of the distressed firms is significantly lower than that of the normal firms. In addition, the firm size of the distressed firms is significantly smaller than that of the normal firms, reaching the significance level of $1 \%(t=7.063)$, but the book-to-market ratio (MB) of the distressed firms is higher because their book value of equity is on the low side in the year of financial distress. In terms of the other firm characteristics, the growth of the normal firms is higher than that of the firms experiencing financial distress, but it does not reach the significance level. The empirical results show that the mean values of the five financial ratios X1-X5 of the distressed firms are negative values and smaller than those of the normal firms, and all reach significant levels. This reveals that the financial indicators of the distressed firms are unsound as compared to those of the normal firms.

Table 4. Difference test ( $\mathrm{t}$ test)

\begin{tabular}{|c|c|c|c|c|c|}
\hline \multirow{2}{*}{ Variables $^{\text {a }}$} & \multicolumn{2}{|c|}{ Normal firms ( $N=\mathbf{2 5 2})$} & \multicolumn{2}{|c|}{$\begin{array}{c}\text { Financially distressed firms } \\
(\mathrm{N}=84)\end{array}$} & \multirow[b]{2}{*}{$\begin{array}{c}\text { Difference Test } \\
\text { ( } t \text {-value })\end{array}$} \\
\hline & Mean & Std. Dev. & Mean & Std. Dev. & \\
\hline SIZE & 7.344 & 1.348 & 6.131 & 1.408 & $7.063 * * *$ \\
\hline MB & 1.323 & 0.992 & 2.979 & 7.300 & $-2.072 * *$ \\
\hline LEV & 0.948 & 1.107 & 5.747 & 8.592 & $-5.106 * * *$ \\
\hline GROWTH & 7.359 & 42.750 & 1.508 & 121.431 & 0.433 \\
\hline ROA & 4.289 & 7.194 & -30.297 & 41.672 & $7.569 * * *$ \\
\hline IT & 0.380 & 0.488 & 0.380 & 0.489 & 0.065 \\
\hline IPO & 9.330 & 6.885 & 10.580 & 6.615 & -1.460 \\
\hline CG_BOD & 1.728 & 0.566 & 1.718 & 0.592 & 0.140 \\
\hline CG_OWN & 2.547 & 0.568 & 2.388 & 0.682 & $1.937 * *$ \\
\hline $\mathrm{X} 1$ & 0.302 & 0.224 & -0.027 & 0.274 & $9.939 * * *$ \\
\hline $\mathrm{X} 2$ & 0.132 & 0.190 & -0.986 & 1.848 & $5.532 * * *$ \\
\hline $\mathrm{X} 3$ & 0.059 & 0.078 & -0.267 & 0.408 & $7.276 * * *$ \\
\hline $\mathrm{X} 4$ & 3.335 & 4.614 & 1.177 & 1.918 & $6.025 * * *$ \\
\hline $\mathrm{X} 5$ & 0.939 & 0.651 & 0.801 & 0.607 & $1.703 *$ \\
\hline C_Score & 0.260 & 0.247 & 0.527 & 1.233 & $-1.977 * *$ \\
\hline C_Score 1 & 0.249 & 0.335 & 0.486 & 0.667 & $-3.117 * * *$ \\
\hline C_Score 2 & 0.110 & 0.310 & 0.140 & 0.385 & -0.771 \\
\hline PC_Score & 0.260 & 0.126 & 0.527 & 0.146 & $-16.155 * * *$ \\
\hline PC_Score1 & 0.249 & 0.151 & 0.486 & 0.145 & $-12.533 * * *$ \\
\hline PC_Score2 & 0.216 & 0.069 & 0.288 & 0.088 & $-6.790 * * *$ \\
\hline
\end{tabular}

a. The definitions of variables: SIZE = firm size, measured by taking the log of the market value of equity; $\mathrm{MB}=$ market value divided by book value; LEV $=$ debt ratio, measured by (long-term liabilities + current liabilities)/market value of equity; the definitions of other variables are the same as in Table 3.

b. ${ }^{* * *}(* *)(*)$ denote significance at the $1 \%(5 \%)(10 \%)$ levels.

From Table 4, the accounting conservatism (C_Score) exhibits no significant difference two years before the distress. In the year of the financial distress and one year before the financial distress, the accounting conservatism (C_Score and C_Score1) of the firms with distress is higher than that of the normal firms. The fitted value of the accounting conservatism (PC_Score) is significantly different in the financial distress year compared with one or two years 
before the financial distress.

Table 5 takes the C_Score as the sample in the year of financial distress, one year before the distress and two years before the distress, and lists the mean values and standard deviations of the C_Score in the financial distress year, one year before the distress and two years before the distress. Thus we use the t-test to test whether the mean values of the variables for different years are significantly different. The findings show that the conservatism (C_Score) for the two years before the financial distress is lower than that in the year of financial distress and one year before the distress, reaching a significance level of $1 \%$. In addition, the degree of conservatism (C_Score) for the financial distress year is higher than that one year before the financial distress and two years before the financial distress, reaching a significance level of $10 \%$. That is, the firms may adopt a non-conservative accounting approach two years before the financial distress. With time, as the accounting conservatism increases, the accounting conservatism is higher in the year of the financial distress. From this, the change in the degree of accounting conservatism (C_Score) is actually related to the occurrence of financial distress.

Table 5. Accounting conservatism (C-Score) subsample t test $(\mathrm{N}=252)$

\begin{tabular}{|c|c|c|c|c|}
\hline \multicolumn{5}{|l|}{ Panel A } \\
\hline \multicolumn{2}{|c|}{ C_Score $_{t-1}$ and C_Score ${ }_{t-2}(\mathrm{~N}=168)$} & \multicolumn{3}{|c|}{ C_Score $_{t}(\mathrm{~N}=84)$} \\
\hline Mean & Std. Dev. & Mean & Std. Dev. & $\begin{array}{c}\text { Difference Test } \\
\text { ( t-value) }\end{array}$ \\
\hline 0.27 & 0.614 & 0.49 & 1.303 & $-1.469^{*}$ \\
\hline \multicolumn{5}{|l|}{ Panel B } \\
\hline \multicolumn{2}{|c|}{ C_Score $_{t}$ and C_Score ${ }_{t-2}(\mathrm{~N}=168)$} & \multicolumn{3}{|c|}{ C_Score ${ }_{t-1}(\mathrm{~N}=84)$} \\
\hline Mean & Std. Dev. & Mean & Std. Dev. & $\begin{array}{r}\text { Difference Test } \\
\text { ( } t \text {-value) }\end{array}$ \\
\hline 0.32 & 0.974 & 0.39 & 0.761 & -0.637 \\
\hline \multicolumn{5}{|l|}{ Panel C } \\
\hline \multicolumn{2}{|c|}{ C_Score $_{t}$ and C_Score ${ }_{t-1}(\mathrm{~N}=168)$} & \multicolumn{3}{|c|}{ C_Score ${ }_{t-2}(\mathrm{~N}=84)$} \\
\hline Mean & Std. Dev. & Mean & Std. Dev. & $\begin{array}{r}\begin{array}{r}\text { Difference Test } \\
\text { ( } t \text {-value) }\end{array} \\
\end{array}$ \\
\hline 0.44 & 1.065 & 0.14 & 0.385 & $3.226 * * *$ \\
\hline
\end{tabular}

\section{Remarks:}

a. $* * *(* *)(*)$ denote significance at the $1 \%(5 \%)(10 \%)$ levels.

b. The definitions of variables: C_Score ${ }_{t}=$ C-Score $=$ accounting conservatism in the year of the financial distress; C_Score ${ }_{t-1}=$ C-Score $1=$ accounting conservatism in the year before the financial distress; $\mathrm{C}_{-}$Score $_{\mathrm{t}-2}=\mathrm{C}-\mathrm{Score} 2$ $=$ accounting conservatism in the two years before the financial distress.

c. The total number of observations is 252 .

d. The mean represents the mean of the C-Score of the subsample.

\subsection{Correlation Coefficients}

This study uses Pearson correlation coefficients to test the correlation between the variables, as shown in Table 6 . Panel A presents the correlation coefficients of the first-stage regression and Panel B the correlation coefficients of the second-stage regression. From Table 6, it can be seen that only the coefficient of correlation between distress and ROA are -0.569 in the first-stage regression equation, and the coefficients of correlation between distress and other variables are less than 0.3. In the second-stage regression equation, the coefficient of correlation between Distress and the fitted value of accounting conservatism (PC_Score) is 0.662, and the coefficient of correlation between the Distress and other variables is close to or less than 0.5 . This indicates that the collinearity problem between the variables is not serious. 
Table 6. Pearson correlation coefficients

\begin{tabular}{|c|c|c|c|c|c|c|c|c|}
\hline \multicolumn{9}{|c|}{ Panel A: First-stage regression (C-Score model) $(\mathrm{N}=336)$} \\
\hline Variables ${ }^{a}$ & C_Score & Distress & GROWTH & ROA & IT & IPO & CG_BOD & CG_OWN \\
\hline C_Score & 1 & & & & & & & \\
\hline Distress & $0.176^{* * *}$ & 1 & & & & & & \\
\hline GROWTH & -0.006 & -0.036 & 1 & & & & & \\
\hline ROA & $-0.150 * * *$ & $-0.569 * * *$ & $0.172 * * *$ & 1 & & & & \\
\hline IT & $-0.135 * *$ & -0.004 & -0.077 & -0.048 & 1 & & & \\
\hline IPO & -0.069 & 0.080 & -0.053 & 0.022 & $-0.163 * * *$ & 1 & & \\
\hline CG_BOD & 0.011 & -0.008 & -0.037 & -0.062 & $0.202 * * *$ & $-0.223 * * *$ & 1 & \\
\hline CG_OWN & -0.086 & $-0.115^{* *}$ & 0.086 & $0.113^{* *}$ & $-0.096^{*}$ & -0.028 & $-0.154 * * *$ & 1 \\
\hline
\end{tabular}

Panel B: Second-stage regression (Financial distress model) $(\mathrm{N}=336)$

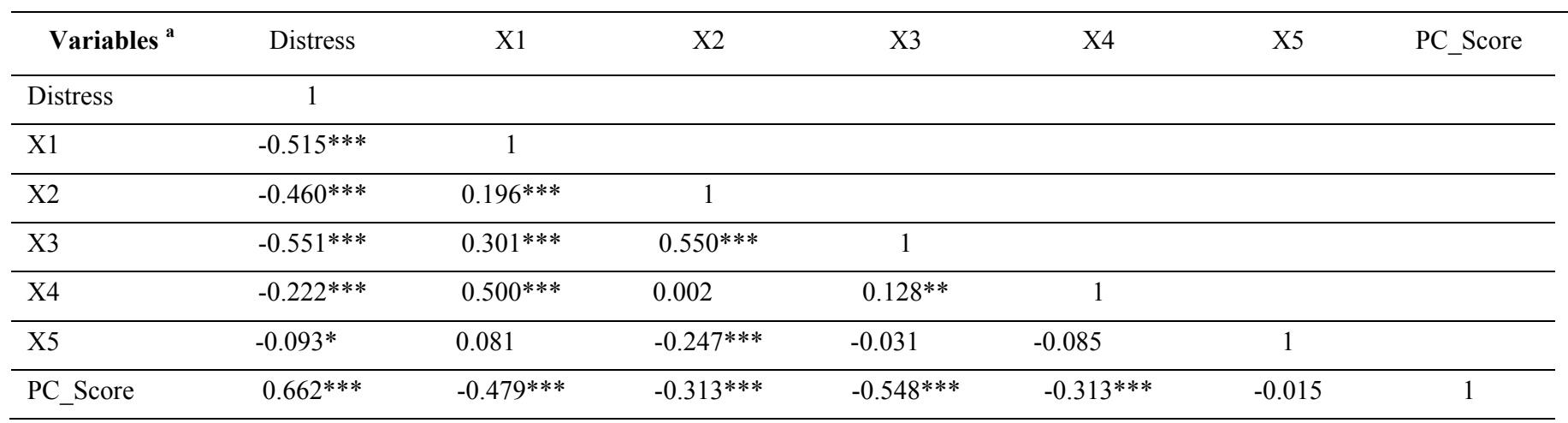

a. The definitions of variables: C_Score = accounting conservatism in the year of financial distress; PC_Score $=$ the fitted value of accounting conservatism in the year of the financial distress. The definitions of other variables are the same as those in Table 3.

b. The left column consists of Pearson correlation coefficients.

c. $* * *(* *)(*)$ denote significance at the $1 \%(5 \%)(10 \%)$ levels.

\subsection{Empirical Results and Analysis}

\subsubsection{Corporate Characteristics and Accounting Conservatism - First-stage Eegression}

Hypothesis 1 mainly discusses the impact of the firm characteristics on accounting conservatism, and Table 7 lists the regression results of the distress year in empirical model 1. The empirical results show that the distress is positively correlated with accounting conservatism (C_Score), reaching the significance level of 5\% (the coefficient is 0.206$)$, The accounting conservatism of the firms with distress is higher than for the normal firms because this study defines financial distress as consisting of bounced checks or a bank run, liquidation and bankruptcy, CPA negative opinions, reforms, being bailed out, a takeover, going private (less than TWD 5 per share in Taiwan), full-cash delivery of stock or going private, tight finance, a shutdown and negative net worth, or no capital increment plan by management. A firm's distress situation as defined by the TEJ is mainly related to worse financial conditions, and the determination of conservatism is related to financial conditions. The empirical results obtained by Liu, et al. (2009) demonstrate the inference that accountants may reduce client financial risk to an acceptable level as the litigation risk increases, and the accountants are more conservative when they review these firms to reduce liquidation risk. Therefore, the degree of accounting conservatism is high in the case of distress. Guan (2006) points out that distressed firms may have the motivation to have a "big bath" in the year of distress to completely write off losses, so a one-time recognition of losses may increase firm conservatism. The above situations may be the causes of the higher conservatism of the distressed firms. 
In addition, GROWTH is negatively correlated with accounting conservatism, and moves along a path opposite to the anticipated direction; it does not reach the significance level (the coefficient is $3.32 \mathrm{e}-06$ ). The ROA is negatively correlated with accounting conservatism, and moves in the opposite way to the anticipated direction; it does not reach the significant level (the coefficient is -0.002). The industry category (IT) is negatively correlated with accounting conservatism, and reaches the significant level of $1 \%$ (the coefficient is -0.222 ). This indicates that the accounting conservatism of the non-electronics industry is higher than that of the electronics industry. The age of firms after an IPO is negatively correlated with accounting conservatism, which reaches a significance level of $10 \%$ (the coefficient is -0.010), and moves in the same direction as anticipated. This indicates that if the age of the firms after an IPO is shorter, the cash flow for future growth cannot be verified, the information asymmetry between managers and investors increases, and the need for accounting conservatism also increases.

In terms of corporate governance characteristics, this study uses the board composition score (CG_BOD) and the equity structure score (CG_OWN) to measure the corporate governance. The empirical results show that the impact of the score for the corporate governance consisting of two dimensions on the accounting conservatism does not reach the significance level. The board composition score (CG_BOD) is positively correlated with the accounting conservatism (the coefficient is 0.006 ), which indicates that the better the corporate governance mechanism is, the greater will be the degree of the accounting conservatism. This result conforms to the complementary perspective, but the evidence is still insufficient. The board composition (CG_OWN) score is inversely correlated with accounting conservatism (the coefficient is -0.088), which indicates that the worse the corporate governance mechanism is, the greater will be the need for accounting conservatism. This result conforms to the substitutive perspective, but the significance level is still insufficient. The above results are the same as the earlier empirical results, in that the correlation between the corporate governance characteristics and accounting conservatism is not consistent.

\subsubsection{Accounting Conservatism Trends and Financial Distress - Second-stage Regression}

Hypothesis 2 mainly discusses the impact of the accounting conservatism trend on the financial distress. Table 8 lists the results of the distress based on the financial data for the distress year using logistic regression. In Table 8, Panel A illustrates the impact of accounting conservatism on the distress, which is estimated by the first-stage regression in the distress year (model 1), one year before the distress (model 2) and two years before the distress (model 3). In Table 8, Panel B illustrates the impact of the accounting conservatism trend and its change on the distress, with accounting conservatism being estimated by the first-stage regression in the distress year (model 1), one year before the distress (model 2) and two years before the distress (model 3).

In Table 8, the empirical results presented in Panel A show the fitted values for accounting conservatism estimated by using first-stage regression in the distress year (PC_Score), one year before the distress (PC_Score1) and two years before the distress (PC_Score2). These values are positively correlated with the distress, reaching significance levels of $1 \%, 1 \%$ and $5 \%$, respectively (the corresponding coefficients are 19.846, 12.438 and 12.232). These results demonstrate that the higher the accounting conservatism, the higher the probability of financial distress as the distressed firms may recognize the losses one time in the year of distress, or the accountants may develop their supervisory function, thus increasing the tendency toward accounting conservatism. By comparing the impact of the accounting conservatism on the distress in the three years, it can be found that the coefficient increases from the two years before the distress as well as from one year before the distress to the year of distress. That is, the impact of the accounting conservatism on the distress becomes greater and greater. These findings are an extension of the results in Table 5, and indicate that the accounting conservatism exhibits an increasing trend before the distress. From the t-tests regarding the differences in the coefficients in models 1 to 3 below Table 8 , it can be found that the impact of accounting conservatism on the distress differs significantly from one year before the distress to the year of distress. The greater degree of accounting conservatism has a greater impact on the financial distress. The difference is significant from one year before the distress to the year of distress. From the above results, it can be deduced that the degree of accounting conservatism significantly increases between one year before the distress and the year of distress. The stakeholders can identify the possibility of financial distress by observing the accounting conservatism.

According to the empirical results of model 4 in Table 8 Panel $\mathrm{B}$, the change in the degree of accounting conservatism (CSCORE_STD) is positively correlated with the distress from two years before the year of distress to the year of distress, and reaches the significance level of $1 \%$ (the coefficient is 33.201). This indicates that the change in the degree of accounting conservatism is related to the occurrence of distress. That is, the greater change in the trend toward accounting conservatism is one of the financial distress signs. The results of models 1 to 3 show that the accounting conservatism trend (CSCORE_TREND2) from two years before the distress to the year of distress is 
positively correlated with the financial distress, which reaches a significance level of $5 \%$ (the coefficient is 0.271 ). The accounting conservatism trend (CSCORE_TREND1) from one year before the distress to the year of distress and the accounting conservatism trend (CSCORE_TREND1_2) from two years before the distress to one year before the distress are positively correlated with the year of distress, but do not reach the significance level (the coefficients are 0.018 and 0.033 ). This indicates that when the firm's accounting conservatism continues to increase, i.e., the accounting conservatism trend exhibits a positive change; this can be viewed as one of the distress signs. However, the evidence is not adequate.

In terms of the control variables, the five financial variables for the Z-score in the accounting conservatism model (Table 8 Panel A) or the accounting conservatism trend (Table 8 Panel B) and the change model have the same direction as anticipated. That is, they all are inversely correlated with the distress, and reach their respective significance levels.

In addition, Table 9 lists the empirical results obtained by using the financial ratios one year before the distress $\left(\mathrm{Xl}_{\mathrm{t}-1}\right.$, $\left.\mathrm{X} 2_{\mathrm{t}-1}, \mathrm{X} 3_{\mathrm{t}-1}, \mathrm{X} 4_{\mathrm{t}-1}, \mathrm{X} 5_{\mathrm{t}-1}\right)$, and the impact of accounting conservatism on the distress. From this, the results regarding the impact of accounting conservatism, and its trend and change on the distress are consistent with the empirical results in Table 8.

Table 7. Corporate characteristics and accounting conservatism - First stage (H1)

\begin{tabular}{lcc}
\hline Variables $^{\text {a }}$ & $\begin{array}{c}\text { Predicted } \\
\text { Sign }\end{array}$ & $\begin{array}{c}\text { Ind. Var.: C_Score } \\
\text { Coefficient }^{\mathbf{b}}\end{array}$ \\
\hline Distress & $?$ & $0.206^{* *}$ \\
GROWTH & + & $(2.06)$ \\
ROA & + & $-3.32 \mathrm{e}-06$ \\
& & $-0.01)$ \\
IT & $?$ & -0.002 \\
& & $(-1.04)$ \\
IPO & - & $-0.222^{* * *}$ \\
& & $(-2.97)$ \\
CG_BOD & $+/-$ & $-0.010^{*}$ \\
& & $(-1.91)$ \\
CG_OWN & $+/-$ & 0.006 \\
& & $(0.09)$ \\
Intercept & & -0.088 \\
\hline Observations & & $(-1.47)$ \\
\hline F-Value & & $0.662^{* * *}$ \\
(P-Value) & & $(2.99)$ \\
\hline Adjusted $R^{2}$ & & 336 \\
\hline
\end{tabular}

a. The definitions of variables are the same as those in Table 3.

b. $t$ statistics are in parentheses; $* * *(* *)(*)$ denote significance at the $1 \%(5 \%)(10 \%)$ levels. 
Table 8. Accounting conservatism trends and financial distress -Sec. stage (H2)

\begin{tabular}{|c|c|c|c|}
\hline \multicolumn{4}{|c|}{ Panel A: Accounting Conservatism and Financial Distress } \\
\hline Variables ${ }^{a}$ & $\begin{array}{c}\text { Model } 1 \\
\text { Ind. Var.: Distress }\end{array}$ & $\begin{array}{c}\text { Model } 2 \\
\text { Ind. Var.: Distress }\end{array}$ & $\begin{array}{c}\text { Model } 3 \\
\text { Ind. Var.: Distress }\end{array}$ \\
\hline $\mathrm{X} 1$ & $\begin{array}{c}-6.528^{* * *} \\
(-2.89)\end{array}$ & $\begin{array}{c}-7.090^{* * *} \\
(-3.27)\end{array}$ & $\begin{array}{c}-5.462^{* * *} \\
(-3.13)\end{array}$ \\
\hline $\mathrm{X} 2$ & $\begin{array}{c}-3.482^{*} \\
(-1.90)\end{array}$ & $\begin{array}{c}-4.056^{*} \\
(-1.79)\end{array}$ & $\begin{array}{c}-2.533^{* * *} \\
(-2.64)\end{array}$ \\
\hline $\mathrm{X} 3$ & $\begin{array}{c}-31.626^{* * *} \\
(-3.55)\end{array}$ & $\begin{array}{c}-30.096^{* * *} \\
(-4.00)\end{array}$ & $\begin{array}{c}-31.278 * * * \\
(-4.92)\end{array}$ \\
\hline $\mathrm{X} 4$ & $\begin{array}{c}-0.686^{*} \\
(-1.94)\end{array}$ & $\begin{array}{l}-0.530^{*} \\
(-1.94)\end{array}$ & $\begin{array}{c}-0.905^{* * *} \\
(-2.77)\end{array}$ \\
\hline $\mathrm{X} 5$ & $\begin{array}{c}-2.221 * * \\
(-2.00)\end{array}$ & $\begin{array}{c}-2.278 * * \\
(-2.38)\end{array}$ & $\begin{array}{c}-2.084 * * \\
(-2.55)\end{array}$ \\
\hline PC_Score & $\begin{array}{c}19.846^{* * * *} \\
(4.02)\end{array}$ & & \\
\hline PC_Score1 & & $\begin{array}{c}12.438^{* * * *} \\
(4.13)\end{array}$ & \\
\hline PC_Score2 & & & $\begin{array}{c}12.232 * * \\
(2.37)\end{array}$ \\
\hline Intercept & $\begin{array}{c}-6.671 * * * \\
(-3.29) \\
\end{array}$ & $\begin{array}{c}-3.580 * * * \\
(-2.77) \\
\end{array}$ & $\begin{array}{l}-1.874 \\
(-1.47) \\
\end{array}$ \\
\hline Observations & 336 & 336 & 336 \\
\hline$\chi^{2}$ & $\begin{array}{c}332.31^{* * *} \\
(0.000)\end{array}$ & $\begin{array}{c}320.89^{* * *} \\
(0.000)\end{array}$ & $\begin{array}{c}297.46^{* * *} \\
(0.000)\end{array}$ \\
\hline Pseudo $R^{2}$ & 0.879 & 0.849 & 0.787 \\
\hline
\end{tabular}

Coefficients Difference Test from Model 1 to Model 3

\begin{tabular}{llc}
\hline PC_Score $=$ PC_Score 1 & $\chi^{2}=1.83$ & P-Value $=0.08^{*}$ \\
PC_Score $=$ PC_Score2 & $\chi^{2}=0.00$ & P-Value $=0.4896$ \\
PC_Score1 $=$ PC_Score 2 & $\chi^{2}=0.84$ & P-Value $=0.1793$ \\
\hline
\end{tabular}

a. The definitions of variables are the same as those in Table 3.

b. $t$ statistics are in parentheses; $* * *(* *)(*)$ denote significance at the $1 \%(5 \%)(10 \%)$ levels. 
Table 8. Accounting conservatism trends and financial distress -Sec. stage (H2) (Con.)

\begin{tabular}{|c|c|c|c|c|}
\hline \multicolumn{5}{|c|}{ Panel B: Accounting Conservatism Trends and Financial Distress } \\
\hline Variables $^{\text {a }}$ & $\begin{array}{l}\text { Model } 1 \\
\text { Ind Var.: } \\
\text { Distress }\end{array}$ & $\begin{array}{c}\text { Model } 2 \\
\text { Ind Var.: Distress }\end{array}$ & $\begin{array}{l}\text { Model } 3 \\
\text { Ind Var.: } \\
\text { Distress }\end{array}$ & $\begin{array}{l}\text { Model } 4 \\
\text { Ind Var.: } \\
\text { Distress }\end{array}$ \\
\hline $\mathrm{X} 1$ & $\begin{array}{c}-4.184 * * \\
(-2.44)\end{array}$ & $\begin{array}{c}-4.623 * * * \\
(-2.79)\end{array}$ & $\begin{array}{c}-4.643 * * * \\
(-2.78)\end{array}$ & $\begin{array}{c}-5.280 * * * \\
(-2.80)\end{array}$ \\
\hline $\mathrm{X} 2$ & $\begin{array}{c}-2.744^{* *} \\
(-2.14)\end{array}$ & $\begin{array}{c}-2.535^{* *} \\
(-2.38)\end{array}$ & $\begin{array}{c}-2.568 * * \\
(-2.32)\end{array}$ & $\begin{array}{c}-2.560 * * * \\
(-2.84)\end{array}$ \\
\hline X3 & $\begin{array}{c}-31.075 * * * \\
(-5.22)\end{array}$ & $\begin{array}{c}-29.697 * * * \\
(-5.33)\end{array}$ & $\begin{array}{c}-30.091 * * * \\
(-5.31)\end{array}$ & $\begin{array}{c}-29.871 * * * \\
(-4.92)\end{array}$ \\
\hline $\mathrm{X} 4$ & $\begin{array}{c}-0.929 * * * \\
(-2.91)\end{array}$ & $\begin{array}{c}-0.827 * * * \\
(-2.73)\end{array}$ & $\begin{array}{c}-0.851 * * * \\
(-2.78)\end{array}$ & $\begin{array}{c}-0.752 * * * \\
(-2.88)\end{array}$ \\
\hline $\mathrm{X} 5$ & $\begin{array}{c}-1.727 * * \\
(-2.16)\end{array}$ & $\begin{array}{c}-1.814^{* *} \\
(-2.30)\end{array}$ & $\begin{array}{c}-1.767 * * \\
(-2.26)\end{array}$ & $\begin{array}{c}-1.948 * * * \\
(-3.11)\end{array}$ \\
\hline CSCORE_TREND2 & $\begin{array}{c}0.271 * * \\
(2.46)\end{array}$ & & & \\
\hline CSCORE_TREND1 & & $\begin{array}{l}0.018 \\
(0.33)\end{array}$ & & \\
\hline CSCORE_TREND1_2 & & & $\begin{array}{l}0.033 \\
(0.98)\end{array}$ & \\
\hline CSCORE_STD & & & & $\begin{array}{c}33.201 * * * \\
(4.13)\end{array}$ \\
\hline Intercept & $\begin{array}{l}0.554 \\
(0.92)\end{array}$ & $\begin{array}{l}0.845 \\
(1.42) \\
\end{array}$ & $\begin{array}{l}0.792 \\
(1.35) \\
\end{array}$ & $\begin{array}{c}-1.840 * * \\
(-2.40)\end{array}$ \\
\hline Observations & 336 & 336 & 336 & 336 \\
\hline$\chi^{2}$ & $\begin{array}{c}295.3 * * * \\
(0.000) \\
\end{array}$ & $\begin{array}{c}291.02 * * * \\
(0.000)\end{array}$ & $\begin{array}{c}291.18 * * * \\
(0.000)\end{array}$ & $\begin{array}{c}314.84 * * * \\
(0.000)\end{array}$ \\
\hline Pseudo $R^{2}$ & 0.781 & 0.770 & 0.771 & 0.833 \\
\hline
\end{tabular}

a. The definitions of variables: CSCORE_TREND2: Accounting conservatism trend from two years before the financial distress to the year of the financial distress. $=($ PC_Score - PC_Score2)/PC_Score2; CSCORE_TREND1: Accounting conservatism trend from one year before the financial distress to the year of the financial distress. $=$ (PC_Score - PC_Score1)/PC_Score1; CSCORE_TREND1_2: Accounting conservatism trend from two years before the financial distress to one year before the financial distress. $=($ PC_Score1 - PC_Score2 $) /$ PC_Score2; CSCORE_STD: Accounting conservatism variation from two years before the financial distress to the year of the financial distress, taking the standard deviation of fitted values of the C_Score from the year of distress to two years before the distress. The definitions of other variables are the same as those in Table 3 .

b. $t$ statistics are in parentheses; $* * *(* *)(*)$ denote significance at the $1 \%(5 \%)(10 \%)$ levels. 
Table 9. Accounting conservatism trends and financial distress $\left(\mathrm{X}_{\mathrm{t}-1} \sim \mathrm{X} 5_{\mathrm{t}-1}\right)(\mathrm{H} 2)$

\section{Panel A: Accounting Conservatism and Financial Distress}

\begin{tabular}{|c|c|c|c|}
\hline Variables ${ }^{a}$ & $\begin{array}{c}\text { Model } 1 \\
\text { Ind. Var.: Distress }\end{array}$ & $\begin{array}{c}\text { Model } 2 \\
\text { Ind. Var.: Distress }\end{array}$ & $\begin{array}{c}\text { Model } 3 \\
\text { Ind. Var.: Distress }\end{array}$ \\
\hline$X 1_{t-1}$ & $\begin{array}{c}-6.371 * * * \\
(-3.57)\end{array}$ & $\begin{array}{c}-4.972 * * * \\
(-3.81)\end{array}$ & $\begin{array}{c}-4.169 * * * \\
(-4.01)\end{array}$ \\
\hline$X 2_{t-1}$ & $\begin{array}{l}-2.277 * \\
(-1.71)\end{array}$ & $\begin{array}{l}-2.172 * \\
(-1.69)\end{array}$ & $\begin{array}{l}-0.302 \\
(-0.28)\end{array}$ \\
\hline$X 3_{t-1}$ & $\begin{array}{c}-18.859 * * * \\
(-3.59)\end{array}$ & $\begin{array}{c}-11.942 * * * \\
(-3.37)\end{array}$ & $\begin{array}{c}-13.177 * * * \\
(-4.38)\end{array}$ \\
\hline$X 4_{t-1}$ & $\begin{array}{l}-0.032 \\
(-0.29)\end{array}$ & $\begin{array}{l}-0.031 \\
(-0.41)\end{array}$ & $\begin{array}{l}-0.137 \\
(-1.47)\end{array}$ \\
\hline$X 5_{t-1}$ & $\begin{array}{c}-2.949 * * * \\
(-3.05)\end{array}$ & $\begin{array}{c}-1.587 * * \\
(-2.38)\end{array}$ & $\begin{array}{c}-1.140 * * \\
(-2.52)\end{array}$ \\
\hline PC_Score & $\begin{array}{c}30.239 * * * \\
(5.41)\end{array}$ & & \\
\hline PC_Score1 & & $\begin{array}{c}16.298 * * * \\
(5.94)\end{array}$ & \\
\hline PC_Score2 & & & $\begin{array}{c}8.759 * * * \\
(3.06)\end{array}$ \\
\hline Intercept & $\begin{array}{c}-10.816^{* * *} \\
(-5.38)\end{array}$ & $\begin{array}{c}-5.815^{* * *} \\
(-5.22)\end{array}$ & $\begin{array}{c}-1.947 * * \\
(-2.49)\end{array}$ \\
\hline Observations & 336 & 336 & 336 \\
\hline$\chi^{2}$ & $\begin{array}{c}316.78^{* * *} \\
(0.000)\end{array}$ & $\begin{array}{c}266.25 * * * \\
(0.000)\end{array}$ & $\begin{array}{c}191.97 * * * \\
(0.000)\end{array}$ \\
\hline Pseudo $R^{2}$ & 0.838 & 0.705 & 0.508 \\
\hline
\end{tabular}

a. The definitions of variables: $\mathrm{X} 1_{\mathrm{t}-1}=$ working capital divided by total assets in one year before financial distress; $\mathrm{X} 2_{\mathrm{t}-1}=$ retained earnings divided by total assets in one year before financial distress; $\mathrm{X} 3_{\mathrm{t}-1}=$ net income before tax and interest divided by total assets in one year before financial distress; $\mathrm{X} 4_{\mathrm{t}-1}=$ market value of equity divided by total liabilities in one year before financial distress; $\mathrm{X} 5 \mathrm{t}-1=$ sales revenue divided by total assets in one year before financial distress. The definitions of other variables are the same as those in Table 3.

b. $t$ statistics are in parentheses; $* * *(* *)(*)$ denote significance at the $1 \%(5 \%)(10 \%)$ levels. 
Table 9. Accounting conservatism trends and financial distress $\left(\mathrm{X}_{\mathrm{t}-1} \sim \mathrm{X} 5_{\mathrm{t}-1}\right)(\mathrm{H} 2)$

\begin{tabular}{|c|c|c|c|c|}
\hline \multicolumn{5}{|c|}{ Panel B: Accounting Conservatism Trends and Financial Distress } \\
\hline Variables $^{\text {a }}$ & $\begin{array}{l}\text { Model } 1 \\
\text { Ind. Var.: } \\
\text { Distress } \\
\end{array}$ & $\begin{array}{l}\text { Model } 2 \\
\text { Ind. Var.: } \\
\text { Distress }\end{array}$ & $\begin{array}{l}\text { Model } 3 \\
\text { Ind. Var.: } \\
\text { Distress }\end{array}$ & $\begin{array}{l}\text { Model } 4 \\
\text { Ind. Var.: } \\
\text { Distress }\end{array}$ \\
\hline $\mathrm{X} 1_{\mathrm{t}-1}$ & $\begin{array}{c}-3.539 * * * \\
(-3.51)\end{array}$ & $\begin{array}{c}-3.967 * * * \\
(-3.97)\end{array}$ & $\begin{array}{c}-3.871 * * * \\
(-3.88)\end{array}$ & $\begin{array}{c}-3.837 * * * \\
(-3.32)\end{array}$ \\
\hline $\mathrm{X} 2_{\mathrm{t}-1}$ & $\begin{array}{l}-0.689 \\
(-0.71)\end{array}$ & $\begin{array}{l}-0.424 \\
(-0.44)\end{array}$ & $\begin{array}{l}-0.481 \\
(-0.50)\end{array}$ & $\begin{array}{l}0.104 \\
(0.11)\end{array}$ \\
\hline $\mathrm{X} 3_{\mathrm{t}-1}$ & $\begin{array}{c}-14.182 * * * \\
(-4.83)\end{array}$ & $\begin{array}{c}-14.219 * * * \\
(-4.90)\end{array}$ & $\begin{array}{c}-13.800^{* * *} \\
(-4.84)\end{array}$ & $\begin{array}{c}-16.197 * * * \\
(-4.97)\end{array}$ \\
\hline $\mathrm{X} 4_{\mathrm{t}-1}$ & $\begin{array}{c}-0.195^{*} \\
(-1.85)\end{array}$ & $\begin{array}{l}-0.164 \\
(-1.59)\end{array}$ & $\begin{array}{c}-0.174 * \\
(-1.66)\end{array}$ & $\begin{array}{l}-0.035 \\
(-0.49)\end{array}$ \\
\hline$X 5_{t-1}$ & $\begin{array}{c}-0.911 * * \\
(-2.07)\end{array}$ & $\begin{array}{c}-1.034 * * \\
(-2.42)\end{array}$ & $\begin{array}{c}-0.977 * * \\
(-2.30)\end{array}$ & $\begin{array}{c}-1.042^{* *} \\
(-2.04)\end{array}$ \\
\hline CSCORE_TREND2 & $\begin{array}{c}0.452 * * * \\
\quad(3.59)\end{array}$ & & & \\
\hline CSCORE_TREND1 & & $\begin{array}{l}0.232 \\
(1.41)\end{array}$ & & \\
\hline CSCORE_TREND1_2 & & & $\begin{array}{l}0.005 \\
(0.22)\end{array}$ & \\
\hline CSCORE_STD & & & & $\begin{array}{c}35.347 * * * \\
\quad(6.23)\end{array}$ \\
\hline Intercept & $\begin{array}{l}-0.262 \\
(-0.67) \\
\end{array}$ & $\begin{array}{l}0.100 \\
(0.26) \\
\end{array}$ & $\begin{array}{l}0.086 \\
(0.23) \\
\end{array}$ & $\begin{array}{c}-2.976^{* * *} \\
(-4.68) \\
\end{array}$ \\
\hline Observations & 336 & 336 & 336 & 336 \\
\hline$\chi^{2}$ & $\begin{array}{c}192.05^{* * *} \\
(0.000)\end{array}$ & $\begin{array}{c}183.42^{* * *} \\
(0.000)\end{array}$ & $\begin{array}{c}181.44^{* * *} \\
(0.000)\end{array}$ & $\begin{array}{c}244.02^{* * *} \\
(0.000) \\
\end{array}$ \\
\hline Pseudo $R^{2}$ & 0.508 & 0.485 & 0.480 & 0.646 \\
\hline
\end{tabular}

a. The definitions of variables are the same as those in Table 3, Table 9 Panel A and Table 9 Panel B.

b. $t$ statistics are in parentheses; $* * *(* *)(*)$ denote significance at the $1 \%(5 \%)(10 \%)$ levels.

\subsection{Additional Test}

\subsubsection{Considering the Big 4 CPA Firms}

The financial reports verified by the Big Four CPA Firms (Balsam et al., 2003; Craswell et al., 1995) are considered to be of higher audit quality than those audited by other firms, and their audited financial reports are reliable because of due diligence. The empirical results based on the verification by the Big Four CPA Firms (BIG4) are positively correlated with accounting conservatism, but do not reach the significance level (the correlation coefficient is 0.072 ). If an audit is conducted by a Big Four CPA Firm, the CPA may maintain its audit quality and develop its ability to exercise supervision over the firm, which can increase the firm's accounting conservatism, but the evidence is not sufficient. In addition, the results for the firm characteristics, accounting conservatism and accounting conservatism 
trends and change are basically consistent with the empirical results of this study. This indicates that the empirical results of this study are reliable.

\subsubsection{Additional Measurement of Corporate Governance}

This study uses individual factors consisting of two dimensions for discussion, and also performs a sensitivity analysis based on firm characteristics that have either been verified by the Big Four CPA Firms or not. It is found that the results regarding the impact of various firm characteristics with the exception of the age of firms after an IPO (which is not significant) on accounting conservatism are consistent with the empirical results using regressions based on scores for corporate governance and accounting conservatism. The results of the analysis are not included in this table due to space limitations.

In addition, the individual variables for corporate governance are used to estimate the fitted value of the accounting conservatism, and sensitivity analysis is conducted to discuss the impact of the accounting conservatism trend and change on the financial distress. The only exception is that the trend in accounting conservatism from two years before the distress to the year of distress has no significant impact on the distress (but the direction is the same), while the other results are the same as the existing empirical results. From the results of the sensitivity analysis, the empirical results of this study lend support to the conservatism argument.

\section{Conclusion and Suggestions}

The purpose of this study has been to detect early signs of enterprise financial distress and then to predict the likelihood of that financial distress. It has aimed to explore the impact of the firm's characteristics reflected in the trend of accounting conservatism on financial distress. Firms with different characteristics may choose different degrees of accounting conservatism, and so the self-selection problem exists. As the firm characteristics can endogenously determine the accounting conservatism trends and further affect the occurrence of financial distress, this study uses two-stage least squares (2SLS) to discuss the correlation between the accounting conservatism trends and financial distress.

First of all, it explores the impact of firm characteristics on accounting conservatism. It has been found that the accounting conservatism of the distressed firms is higher than that of the normal firms because the distressed firms may recognize losses at one time in the year of financial distress or as the CPA firms develop their external supervision function, which increases the accounting conservatism of the distressed firms. Secondly, this study verifies the correlation between the accounting conservatism trends and financial distress, which indicates that the accounting conservatism is correlated with the distress. It can be further found that the accounting conservatism trends and the change in the degree of accounting conservatism from the two years before the distress to the year of distress are positively correlated with the distress. This indicates that the probability of the firm experiencing financial distress would be higher if the change in the degree of accounting conservatism and the increment were greater. That is, when the firm's trend toward accounting conservatism changes significantly, this can be viewed as one of the distress signs. From the above, the accounting conservatism trends reflected by different firm characteristics can help determine the probability of the firm experiencing financial distress.

As the financial distress has no consistently recognized definitions, it is recommended that future studies extend the financial distress to the near-financial distress or that the discussion can be based on different definitions of financial distress so as to observe whether the results are different. Although this study makes every effort to obtain rigorous and complete results, there are also some inevitable limitations, for example, the limitations caused by paired sampling.

\section{References}

Ahmed, A. S., \& Duellman, S. (2007). Accounting conservatism and board of director characteristics: An empirical analysis. Journal of Accounting and Economics, 43(2), 411-437. http://dx.doi.org/10.1016/j.jacceco.2007.01.005

Ahmed, A. S., Billings, B. K., Morton, R. M., \& Stanford-Harris, M. (2002). The role of accounting conservatism in mitigating bondholder-shareholder conflicts over dividend policy and in reducing debt costs. The Accounting Review, 77(4), 867-890. http://dx.doi.org/10.2308/accr.2002.77.4.867

Altman, E. I. (1968). Financial ratios, discriminant analysis and the prediction of corporate bankruptcy. The Journal of Finance, 23(4), 589-609. http://dx.doi.org/10.1111/j.1540-6261.1968.tb00843.x

Ball, R., \& Shivakumar, L. (2005). Earnings quality in UK private firms: Comparative loss recognition timeliness. Journal of Accounting and Economics, 39(1), 83-128. http://dx.doi.org/10.1016/j.jacceco.2004.04.001 
Ball, R., Sadka, G., \& Sadka, R. (2009). Aggregate earnings and asset prices. Journal of Accounting Research, 47(5), 1097-1133. http://dx.doi.org/10.1111/j.1475-679X.2009.00351.x

Balsam, S., Krishnan, J., \& Yang, J. S. (2003). Auditor industry specialization and earnings quality. Auditing: A Journal of Practice \& Theory, 22(2), 71-97. http://dx.doi.org/10.2308/aud.2003.22.2.71

Basu, S. (1997). The conservatism principle and the asymmetric timeliness of earnings. Journal of Accounting and Economics, 24(1), 3-37. http://dx.doi.org/10.1016/S0165-4101(97)00014-1

Beaver, W. H., Landsman, W. R., \& Owens, E. L. (2012). Asymmetry in earnings timeliness and persistence: a simultaneous equations approach. Review of Accounting Studies, 17(4), 781-806. http://dx.doi.org/10.1007/s11142-011-9174-3

Beekes, W., Pope, P., \& Young, S. (2004). The link between earnings timeliness, earnings conservatism and board composition: Evidence from the UK. Corporate Governance: An International Review, 12(1), 47-59. http://dx.doi.org/10.1111/j.1467-8683.2004.00342.x

Berkovitch, E., \& Israel, R. (1998). The bankruptcy decision and debt contract renegotiations. European Finance Review, 2(1), 1-27. http://dx.doi.org/10.1023/A:1009738110075

Bushman, R., Chen, Q., Engel, E., \& Smith, A. (2004). Financial accounting information, organizational complexity and corporate governance systems. Journal of Accounting and Economics, 37(2), 167-201. http://dx.doi.org/10.1016/j.jacceco.2003.09.005

Chava, S., \& Jarrow, R. A. (2004). Bankruptcy prediction with industry effects. Review of Finance, 8(4), 537-569. http://dx.doi.org/10.1093/rof/8.4.537

Chen, T. F. (2006). Accounting conservatism, financial distress and institutional holding. Master's dissertation. Department of Accounting, National Chengchi University.

Chi, W., Liu, C., \& Wang, T. (2009). What affects accounting conservatism: A corporate governance perspective. Journal of Contemporary Accounting \& Economics, 5(1), 47-59. http://dx.doi.org/10.1016/j.jcae.2009.06.001

Coles, J. L., Daniel, N. D., \& Naveen, L. (2008). Boards: Does one size fit all? Journal of Financial Economics, 87(2), 329-356. http://dx.doi.org/10.1016/j.jfineco.2006.08.008

Craswell, A. T., Francis, J. R., \& Taylor, S. L. (1995). Auditor brand name reputations and industry specializations. Journal of Accounting and Economics, 20(3), 297-322. http://dx.doi.org/10.1016/0165-4101(95)00403-3

Daily, C. M., \& Dalton, D. R. (1994). Bankruptcy and corporate governance: The impact of board composition and structure. Academy of Management Journal, 37(6), 1603-1617. http://dx.doi.org/10.2307/256801

Francis, J. R., \& Wang, D. (2008). The joint effect of investor protection and big 4 audits on earnings quality around the world. Contemporary Accounting Research, 25(1), 157-191. http://dx.doi.org/10.1506/car.25.1.6

Francis, J., LaFond, R., Olsson, P. M., \& Schipper, K. (2004). Costs of equity and earnings attributes. The Accounting Review, 79(4), 967-1010. http://dx.doi.org/10.2308/accr.2004.79.4.967

Guan, Y. D. (2006). Chinese delisting buffer mechanism and earnings management. China Research. 49(3), 93-118.

Holthausen, R. W., \& Watts, R. L. (2001). The relevance of the value-relevance literature for financial accounting standard setting. Journal of Accounting and Economics, 31(1), 3-75.

Huang, W.T. (2009). Accounting conservatism, financial distress and corporate governance-Evidence in China. Master's dissertation. Department of Accounting, Fu Jen Catholic University.

Jensen, M. C., \& Meckling, W. H. (1976). Theory of the firm: Managerial behavior, agency costs, and ownership structure. Journal of Financial Economics, 3(4), 78-79, 305.

Khan, M., \& Watts, R. L. (2009). Estimation and empirical properties of a firm-year measure of accounting conservatism. Journal of Accounting and Economics, 48(2), 132-150.

La Porta, R., Lopez-de-Silanes, F., Shleifer, A., \& Vishny, R. (1999). The quality of government. Journal of Law, Economics, and Organization, 15(1), 222-279. http://dx.doi.org/10.1093/jleo/15.1.222

LaFond, R., \& Roychowdhury, S. (2008). Managerial ownership and accounting conservatism. Journal of Accounting Research, 46(1), 101-135. http://dx.doi.org/10.1111/j.1475-679X.2008.00268.x

LaFond, R., \& Watts, R. L. (2008). The information role of conservatism. The Accounting Review, 83(2), 447-478. http://dx.doi.org/10.2308/accr.2008.83.2.447 
Lara, J. M. G., Osma, B. G., \& Penalva, F. (2009). Accounting conservatism and corporate governance. Review of Accounting Studies, 14(1), 161-201. http://dx.doi.org/10.1007/s11142-007-9060-1

Lee, T. S., \& Yeh, Y. H. (2004). Corporate governance and financial distress: Evidence from Taiwan. Corporate Governance: An International Review, 12(3), 378-388. http://dx.doi.org/10.1111/j.1467-8683.2004.00379.x

Liu, C. W., Wang, T. C., \& Lai, S. T. (2009). Litigation Risk and Large Audit Firms' Acceptable Level of Clients' Financial Risk. NTU Management Review, 20(1), 1-40.

Ohlson, J. A. (1980). Financial Ratios and the Probabilistic Prediction of Bankruptcy. Journal of Accounting Research, 18(1), 109-131. http://dx.doi.org/10.2307/2490395

Ramalingegowda, S., \& Yu, Y. (2012). Institutional ownership and conservatism. Journal of Accounting and Economics, 53(1), 98-114. http://dx.doi.org/10.1016/j.jacceco.2011.06.004

Rezaee, Z. (2005). Causes, consequences, and deterence of financial statement fraud. Critical Perspectives on Accounting, 16(3), 277-298. http://dx.doi.org/10.1016/S1045-2354(03)00072-8

Roychowdhury, S., \& Watts, R. L. (2007). Asymmetric timeliness of earnings, market-to-book and conservatism in financial reproting. Journal of Accounting and Economics, 44(1-2), 2-31. http://dx.doi.org/10.1016/j.jacceco.2006.12.003

Shumway, T. (2001). Forecasting bankruptcy more accurately: A simple hazard model. The Journal of Business, 74(1), 101-124. http://dx.doi.org/10.1086/209665

Sterling, R. R. (1970). Theory of the measurement of enterprise income: University Press of Kansas.

Wang, C. C., Pan, H. H., \& Chi, W. C. (2012). Measure of accounting conservatism for Taiwan firms: Applicability of C-Score. Review of Accounting and Auditing Studies, 2(2), 1-31.

Watts, R. L. (2003a). Conservatism in accounting Part I: Explanations and implications. Accounting Horizons, 17(3), 207-221. http://dx.doi.org/10.2308/acch.2003.17.3.207

Watts, R. L. (2003b). Conservatism in accounting Part II: Evidence and research opportunities. Accounting horizons, 17(4), 287-301. http://dx.doi.org/10.2308/acch.2003.17.4.287

Zmijewski, M. E. (1984). Methodological issues related to the estimation of financial distress prediction models. Journal of Accounting Research, 22(Supplement), 59-82. http://dx.doi.org/10.2307/2490859 